\title{
Strategies and Effects of LEDS (Low Emission Development Strategy) in Fortaleza, Brazil
}

\author{
C.B. NERES ${ }^{1}$, F.M. CunhA ${ }^{2}$, M.F. CARVALHO ${ }^{3}$ \\ 1-3University of Debrecen, Faculty of Engineering, Department of Civil Engineering, Debrecen, Hungary \\ calubarreto@gmail.com,francielemarquescunha@gmail.com,matheusfc.engcivil@gmail.com
}

\begin{abstract}
When it comes to climate change, the built environment, together with transport, and waste and water management play a significant role as Greenhouse Gases (GHG) emitting sectors, reflecting the strong need to address such issues by local governments. A notable action that has been taken in this regard is the Urban Low Emission Development Strategies (Urban LEDS), which consists of a project implemented by the UN-Habitat and the International Council for Local Environmental Initiatives (ICLEI) that selected eight model cities and twenty-one satellite cities around the world and aims to support integrated and ambitious climate action, encouraging lowcarbon efforts in emerging economies through the collaboration among them. In addition, eight European cities also participated in the project in its first phase, contributing with their expertise and experience with climate change mitigation. Since 2012, the city of Fortaleza in Brazil is a model city of the Urban LEDS project and it has sustainably integrated and developed many projects, making it a more resilient city, stimulating its economic growth and improving its quality of life. This paper aims to present the milestones that Fortaleza has already met within Urban LEDS and its main priorities in the next years, identifying best practices in three European cities (Copenhagen, Zagreb and Hannover) that could also be implemented in its geographical, social and cultural context, as well as indicate lessons that other cities can learn from Fortaleza.
\end{abstract}

Keywords: Urban LEDS, GHG Emissions, Climate Change Mitigation

\section{Introduction}

In the last few decades, environmental activists, country leaders, non-governmental organizations, scientists and the active community have summed efforts to minimize climate changes. Among such efforts is the Urban Low Emission Development Strategies (Urban-LEDS), a project conducted by the UN-Habitat and the International Council for Local Environmental Initiatives (ICLEI), which supports local governments globally, promoting actions for diminishing Greenhouse Gases emissions, based on the methodology of ICLEI's GreenClimateCities, which provides a step-by-step guide to neutralize the emissions through sustainable actions.

The project was launched in its first phase in 2012, engaging 37 cities in 12 countries around the world, among which were Brazil, Indonesia, India and South Africa. The LEDS project also selected cities in Europe to contribute with their best practices and knowledge with emerging cities, in order to develop the best plans and actions to minimize the effects of climate change. For its second phase (2017-2021) it now includes four more countries from emerging economies, resulting in a total of 60 cities involved. 
One of the model cities chosen for Phase 1 of the Urban-LEDS project is Fortaleza, which is the fifth most populated city in Brazil, with an estimated population of 2.6 million people in 2020. The criteria that led Fortaleza to be selected as a model city considered its geography and population, the commitment with policies for low carbon emission, and also the affinity between pre-existing projects in Fortaleza and the initiatives to be implemented by the ICLEI proposals.

The committed and accomplished goals of Fortaleza in both phases of the Urban-LEDS project are presented along this paper and show that, although it has been selected as a model city, there are still opportunities to elevate the standard to be taken in the satellite cities in Brazil, as well as possibilities to adopt and get inspired by other model cities around the world, mainly in Europe. Therefore this paper investigates how Fortaleza can achieve higher levels of sustainable standards, which European cities could set examples for Fortaleza in the fields of urban mobility and transportation, waste management, renewable and efficient energy, urban planning and spatial development, taking into account its urban built environment and patterns of GHG emissions levels, as well as what actions Fortaleza should implement in order to encourage best practices in other Brazilian cities.

\section{Literature Review}

\subsection{Fortaleza as an Urban LEDS model city}

The efforts of Fortaleza to become a more resilient city, with growing economy and better quality of life through the implementation of more sustainable measures began before it became a model city in the Urban LEDS initiative. Actually, its commitment to low carbon emissions policies was one of the reasons that made it stand out among other cities and get selected to be part of the project [1].

The master plan of Fortaleza elaborated in 2009 represented a milestone for the urban planning of the municipality, as for the first time, the socio-environmental dimension of a plan was placed as the foundation and direction of urban development policies [2]. The plan's environmental and urban macroplanning was proposed according to the fragility and potential indications of the geo systemic compartments, i.e. it defined preservation, recovery and environmental interest zones, delimited special zones for preservation of the landscape, historical and cultural heritage, as well as zones of social interest. Furthermore, it also emphasized the treatment of urban drainage in the form of rainwater management, proposed a system of green areas and the use of soil permeability rates as an urban parameter that regulates land occupation.

However, before joining the Urban-LEDS project, Fortaleza lacked a comprehensive approach and expertise to tackle climate change. Aware of that, in the beginning of the city's journey as a member of Urban-LEDS in 2013, it reinforced its commitment to sustainable actions and took charge of its low emission development using the GreenClimateCities (GCC) methodology to Analyze, Act and Accelerate local climate action [3].

\subsubsection{Fortaleza actions within Urban LEDS Phase I}

Fortaleza's first effort under the Urban LEDS project was to create its first GHG Emissions Inventory and use its outcomes as a decision-making tool, as the GHG inventory is a key component of the GCC 
methodology to assist on the establishment of priority actions and measurable progress indicators and metrics [3].

The inventory showed that the main economic activities in Fortaleza are tourism, industry and commerce, and identified that the main sectors responsible for the major GHG emissions are waste, mobility, urban planning and spatial development, street lighting and renewable energy, resulting in most of the adopted measures to be related to these areas, specially mobility and transport, as during the first Urban-LEDS meetings, municipal technicians and local authorities argued that transport could be the main driver of GHG emissions, as well as the best opportunity to transformatively promote low emission development.

The GHG Emissions Inventory and the other additional initiatives created the necessary conditions for the elaboration of the Low Carbon Urban Development Policy of Fortaleza, which was established through the Law 10.586 in 2017, and contains guidelines, objectives and instruments that guide the city development, incorporating issues related to socio-environmental sustainability.

Considering the Low Carbon Plan of Fortaleza [4], the planned actions and their expected results in each of the priority sectors in Fortaleza are shown on Table 1.

\begin{tabular}{|c|c|c|c|c|}
\hline \multirow{5}{*}{$\begin{array}{l}\text { Transport and } \\
\text { Mobility }\end{array}$} & Action & Year & Target & Potential Reduction $\left(\mathrm{tCO}_{2 \mathrm{e}}\right)$ \\
\hline & \multirow{2}{*}{$\begin{array}{l}\text { Expansion of the } \\
\text { cycling network - } \\
\text { bicycle lanes, bike } \\
\text { lanes and routes }\end{array}$} & 2020 & $236.2 \mathrm{~km}$ & 36,000 \\
\hline & & 2030 & $526 \mathrm{~km}$ & 98,000 \\
\hline & \multirow[t]{2}{*}{ Bike sharing } & 2020 & 4,000 bikes & 1,370 \\
\hline & & 2030 & 12,000 bikes & 4,100 \\
\hline \multirow[t]{4}{*}{ Waste } & \multirow{2}{*}{$\begin{array}{l}\text { Recycling of Solid } \\
\text { Waste }\end{array}$} & 2020 & $20 \%$ & 21,165 \\
\hline & & 2030 & $40 \%$ & 47,093 \\
\hline & \multirow[t]{2}{*}{ Composting } & 2020 & $10 \%$ & 38,875 \\
\hline & & 2030 & $20 \%$ & 78,099 \\
\hline \multirow[t]{4}{*}{ Energy } & \multirow{2}{*}{$\begin{array}{l}\text { Energy efficiency } \\
\text { and use of LED } \\
\text { light products }\end{array}$} & 2020 & $30 \%$ & 2,240 \\
\hline & & 2030 & $60 \%$ & 6,415 \\
\hline & \multirow{2}{*}{$\begin{array}{l}\text { Retrofit of public } \\
\text { buildings }\end{array}$} & 2020 & $20 \%$ of buildings & 1,758 \\
\hline & & 2030 & $50 \%$ of buildings & 6,290 \\
\hline \multirow[t]{2}{*}{ Construction } & \multirow{2}{*}{$\begin{array}{l}\text { Green Factor - } \\
\text { Sustainability } \\
\text { Certification }\end{array}$} & 2020 & $5 \%$ reduction & 8,950 \\
\hline & & 2030 & $20 \%$ reduction & 38,000 \\
\hline
\end{tabular}

\section{Table 1. Actions and targets through Urban LEDS in Fortaleza}

When it comes to Transport and Mobility, the bike sharing scheme in Fortaleza, launched in December 2014, was responsible for the reduction in emissions of $400 \mathrm{tCO}_{2 \mathrm{i}}$ in 2015, and currently counts with 6.7 daily trips per bike, the highest rate in Brazil (compared to 5 in Rio de Janeiro and 2.3 in Brasilia). In addition, in 2012, the city had $68.6 \mathrm{~km}$ of bicycle lanes, while by December 2015, there were $131.6 \mathrm{~km}$ implemented and the improvements made in the expansion of bike lanes and cycle paths are estimated to have reduced 11,000 tons of $\mathrm{CO}_{2 \mathrm{e}}$ emissions in 2015 alone [3]. 
The municipality also created an Integrated Waste Management Plan and a Recycling Attitudes Program, resulting in less waste sent to the Caucaia landfill (1,758 million tons of waste in 2011) with the use of a biogas plant founded in 2018, creation of 13 local sorting and recycling centers as well as support to 39 waste picker cooperatives to improve social equity and support green jobs creation.

Furthermore, Fortaleza created a certification for sustainable construction called Fator Verde 'Green Factor', which encouraged the use of solar thermal systems and photovoltaic panels on low-income households for heating water and electricity, besides retrofit of 13 schools to energy efficient standards.

Besides the measures shown in Table 1, Fortaleza presented other actions regarding Transport and Mobility in its Climate Change Bill, finalized in 2015, which also included a Bus Rapid Transit and an electric car sharing system.

The target set by Fortaleza in regards to an electric car sharing system (VAMO) is to introduce at least 500 electric cars by 2030. Currently the system, which was implemented in 2016 with no costs to the municipal budget, inspired by similar systems in Paris and Barcelona, counts with 15 electric cars and 13 stations. In addition, a study developed in 2018 based on data gathered during the first year of the project, shows that a reduction in $10 \%$ of the GHG emissions would be possible with a fleet of 12 thousand electric cars by 2050 [5].

In regards to the Bus Rapid Transit system, only in 2015, the exclusive bus lanes were estimated to contribute to reducing over 229,000 tons of $\mathrm{CO}_{2 \mathrm{e}}$ emissions and by February 2016, 25 dedicated bus lanes stretching $135 \mathrm{~km}$ were implemented.

\subsubsection{Fortaleza actions within Urban LEDS Phase II (2017-2021)}

The second phase of Urban-LEDS, which is aligned with the Paris Agreement, started in 2017 and has provided technical assistance to 60 cities and towns in 8 countries with exchanges with 16 European cities, helping them develop robust strategies and integrated climate action plans, underpinned by knowledge gained from risk \& vulnerability assessments and greenhouse gas emission inventories [6].

Fortaleza finished its participation in the first phase of Urban-LEDS with the vision to become a leading eco-efficient and resilient city that allies economic growth with environmental conservation and drastic GHG emissions reduction, as well as being committed to renewable energy and implementing an efficient waste management policy. Most of the tasks allocated among the GCC methodology were completed, with a few aspects requiring improvements such as the development of enabling policies and regulations, establishment of connections with similar cities worldwide, inspiring other cities and gaining recognition.

Thus, in August 2018, Fortaleza confirmed its interest to participate in Urban-LEDS phase II and prioritise actions in the energy and transport sectors, including in its agenda for 2019 peer to peer learning and exchange between project cities on these two crucial topics.

In this new phase of Urban-LEDS, the mayor of Fortaleza affirms that the city has reached a level of maturity and accumulated knowledge that will allow them to take bigger steps on the path to low carbon development. The city aims to create a plan to adapt to climate change, through creating more inclusive public policies, generating jobs and, at the same time, driving the achievement of sustainable development. As an example of what Fortaleza has already accomplished during the second phase is the 
Sustainable Transport Award of the Institute for Transport and Development Policies (ITDP), which the city won in 2018 for the implementation of good practices in sustainable transport and traffic safety.

\subsection{European Initiatives}

As previously mentioned, an aspect which Fortaleza included in its objectives for the second phase of Urban-LEDS is to connect with similar cities and peer learn through their examples. Three European cities which could inspire improvements in Fortaleza, due to projects they have implemented in regards to issues that also affect Fortaleza are Copenhagen, in Denmark, Zagreb, in Croatia and Hannover in Germany.

\subsubsection{Copenhagen, Denmark - the Nørrebrogade road}

Copenhagen is the largest city in Denmark, with a population of approximately 2 million people. Copenhagen's economy is diverse in several sectors, mainly business and services (covering $17 \%$ of regional employment), retail (15.8\%) and public services, such as social institutions (13.2\%), education $(8.5 \%)$ and public administration (8.2\%). [7]

Copenhagen is known as a sustainable city with high use of bicycles, however, in the last decades, the city has still faced challenges in regards to its main roads, such as the Nørrebrogade road, heavily congested with the traffic of private vehicles [8].

According to the 2015 ICLEI case study on Copenhagen, in 2008, the two-kilometer Nørrebrogade road that connects central Copenhagen to its suburban periphery, was used by an average of 30,345 cyclists, 15,120 cars, 30,000 bus passengers and 6,525 pedestrians per day. The narrow road design puts public transport users, cyclists and pedestrians in direct competition with private vehicles, resulting in frequent traffic jams and related safety issues. In addition, the limited space on the sidewalk has negative economic and social effects, as the lack of space for pedestrians is not favorable for residents and tourists to enjoy the more than 300 shops, restaurants and services located along Nørrebrogade road [8].

In 2006, in order to solve these problems and also in order to make the city become carbon neutral by 2025, Copenhagen local authorities started to develop the Nørrebrogade Plan as part of their "EcoMetropolis" program. The plan had two stages. Phase I comprised a traffic test from October 2008 to June 2010, followed by a construction phase from 2010 to 2012, between the bridge over the river (Dronning Louises Bro) and Nørrebros Runddel. Phase II concentrated on an additional section, between Nørrebros Runddel and the Nørrebro train station (Borgmestervangen - Esromgade), with construction starting in autumn 2014 and completed in 2015 [8].

The first phase of the Nørrebrogade project generated successful results, which reinforced additional increases in traffic calming measures to be pursued during Phase II, including, increase in the efficiency of public transport and the number of passengers, reduction in the use of cars and improvements on traffic safety, increase in the total number of cyclists and revitalization of the social utility of the road. 
In 2008, before the start of the second phase of the project, the city hall conducted a public opinion survey on the project and the result was that a clear majority of residents were in favor of the changes and $58 \%$ of the pedestrians interviewed appreciated the experience [8].

\subsubsection{Zagreb - Energy Efficient city (ZAGEE)}

The city of Zagreb is the capital of Croatia and its dominant urban, administrative, political, financial, economic and educational center with a total of 790,017 inhabitants and 17 districts. Zagreb attracts the majority of daily travelers from its regional surroundings, more than 100,000 who travel to Zagreb for work or education [9].

Zagreb has conceived a wide range of projects led by the local government aimed at sustainable development, among them the innovative ZagEE initiative, which was developed to achieve energy savings for public buildings and public lighting systems, through technologies and economically viable and energy efficient measures.

The objective of the ZagEE project was to make buildings owned by the local public authority (city of Zagreb) more energy efficient and renewable energy sources, the project lasted for four years between 2013 and 2017, developed within the framework of Intelligent Energy Europe (IEE) program.

According to the European Commission's description of the project at the IEE program, the ZagEE project can be divided into two specific investments: renovation of public buildings and public lighting. The rehabilitation of public buildings included standardized energy efficiency renovation measures, but also the installation of renewable energy sources (solar panels and collectors) in the same buildings [10].

The modernization of public lighting was the first project of this size in Croatia featuring LED lamps with dimming at night. By implementing the proposed project measures, an energy saving of 33,526 MWh per year was achieved, as well as $290 \mathrm{MWh}$ of green electricity generated [10].

At the Intelligent Energy Europe (IEE) project database website it is possible to find details and results of the project, such as: public buildings became more self-sustainable, through the introduction of energy efficiency measures and renewable energy sources; the training of public administration officials in project management and potential for replication in other parts of Croatia and the wider region; identification of legislative, financial and technical issues that may arise during the project, in order to initiate changes in legislation, regulation and improvement of existing financial instruments; and provision of a healthier and more comfortable environment for public administration employees, students, children and the elderly as well as stimulation of other sectors of the economy, creating new employment opportunities and promoting economic development [10].

\subsubsection{Hannover: Klima-Alliance}

Hannover, the capital of Lower Saxony Land in northwest Germany, was chosen to be analysed in this paper because it joined with citizens, companies, energy suppliers and organizations to form the KlimaAlliance with the aim of reducing greenhouse gas emissions by $40 \%$ by 2020 . A diverse group of stakeholders identified several activities and implementation measures at the local level, including renovation, modernization and construction of energy-efficient buildings and promotion of the use of smart energy and sustainable energy generation. 
According to a report made by the local authorities of Hannover called "Climate Alliance Hannover 2020: a strong alliance for climate protection" from 2010, the initial challenge was 1.8 million tons of CO2 per year until 2020 determined by the main stakeholders in industry, commerce and society. The process was controlled by a committee that included the Directorate of Economic and Environmental Services, the city treasury department and the board of directors of entities. A core team of city planners, facility managers, climate protection experts, energy suppliers, power supply operators and corporate strategists organized the process. This support helped all stakeholders to agree on ambitious but realistic measures [11].

At the beginning of the Climate Alliance in 2007 the mayor invited representatives from industry, housing companies and various associations and citizen groups to work together on task forces. They started by formulating concrete steps for climate protection. In June 2008, a new climate protection action program was released to the public, and on December 11, 2008, the City Council Assembly confirmed the legally binding status of the agreed reduction targets [11].

Initiators and sponsors of the Climate Alliance, the municipal administration and concessionaires have also set ambitious goals for themselves. The city administration has implemented $\mathrm{CO}_{2}$ reduction measures in all areas under its control. The most valuable lessons that can be learned from the Hannover study are: emphasis on energy efficient renovation of all older municipal buildings, construction of all new buildings with the incorporation of climate protection priorities in urban planning, municipal tenders and land sales, and intelligent use of energy with energy efficiency in building management and procurement of materials, efficient public lighting and traffic signalling systems.

\section{Data and Methods}

The methodology used in this paper was based on identifying similarities between Fortaleza and three European cities (Copenhagen, Zagreb and Hannover), in order to determine the best projects and practices that could also be adapted to a Brazilian metropolis environment. As previously mentioned, the criteria for comparison among European cities and Fortaleza considered geographical aspects and demographic characteristics, such as: location, size, relief, weather, population size, population density, age and ethnics groups. Based on these aspects, huge European coastal cities or near to the sea, populated metropolis with a population density around 8,000 people by $\mathrm{km}^{2}$, preferably humid and with high temperature most part of the year were considered.

Another topic that was addressed is the economic aspect. Fortaleza has an important commercial polo reference to all the Northeast region of Brazil. There are industries for clothes, shoes and mainly leather goods for internal use and even though export to other countries; in the last years tourism has hugely grown in the city, which has impacted the economy highly, as well as brought more people to develop the commerce and industry sectors. Among the European cities in the LEDS project, tourism seemed to be a potential reference for economic criteria of comparison, since it is one of the most important sectors of economy in Europe, mainly in cities located on the coast side.

When it comes to socio-cultural aspects, Fortaleza reflects some issues that can be found in the whole Brazilian territory, such as: high level of social inequalities, urban violence, neighborhoods with precarious infrastructure and housing conditions. As a city in development to improve the current social 
condition, the arrangement of the previously mentioned aspects, with the implementation of practices that aim at social equality and the right of access to the population, can result in a positive impact on the social context.

Finally, a last indicator used to compare Fortaleza with European cities, concerning harmful gases emissions, was the annual emissions rate. The ICLEI in the Urban LEDS's project explores this information through the economic activities, and the impact from each city sector to mitigate the negative impact of the GHG emissions.

\section{Results and Discussions}

All data mentioned in the previous topics, which was used to compare Fortaleza with the selected European cities, can be found in Tables 2 and 3 below.

\begin{tabular}{|c|c|}
\hline \multicolumn{2}{|l|}{ FORTALEZA } \\
\hline Area & $314,93 \mathrm{~km}^{2}$ \\
\hline Population & 2,5 million \\
\hline Population Density & $7.786 \mathrm{inhab} / \mathrm{km}^{2}$ \\
\hline City Budget & USD 1,8 billion (2012) \\
\hline Pop. Annual Growth & 0,75\% (2015-2013 per annum) \\
\hline Major economic activities & Tourism, Industry, Commerce \\
\hline \multicolumn{2}{|l|}{ Energy profile indicators } \\
\hline Energy consumption per inhabitant (MWh/hab/year) & 1.861.506,88 MWh \\
\hline GHG emissions by year: & 1.491.598.261 $\mathrm{tCO}_{2}(2012)$ \\
\hline Annual emissions from the Transport Sector: & $894.958 .956 \mathrm{tCO}_{2}$ \\
\hline$\%$ of population with access to electricity & $99 \%$ \\
\hline$\%$ of population with access to municipal water system & $94 \%$ \\
\hline$\%$ of population served by municipal drainage system & $64 \%$ \\
\hline$\%$ of population served by municipal solid waste collection & $99 \%$ \\
\hline $\begin{array}{l}\% \text { of municipal area served by selective collection of } \\
\text { waste for recycling }\end{array}$ & $25 \%$ \\
\hline Solid waste generation per inhab. (kg/hab/year) & $474,5 \mathrm{~kg} / \mathrm{hab}$ \\
\hline
\end{tabular}




\begin{tabular}{|l|l|}
\hline$\%$ of pop. living in informal settlements & $11,9 \%$ \\
\hline Public transportation modes available: & BRT, Bus, Metro, Bike Sharing Scheme \\
\hline
\end{tabular}

Table 2. Fortaleza's indicators used for comparison with other cities

\begin{tabular}{|c|c|c|c|}
\hline \multicolumn{4}{|l|}{ EUROPEAN CITIES } \\
\hline & Copenhagen & Hannover & Zagreb \\
\hline Area & $179,8 \mathrm{~km}^{2}$ & $204 \mathrm{~km} 2$ & $202,4 \mathrm{~km}^{2}$ \\
\hline Population & 0,59 million & 0,56 million & 0,79 million \\
\hline Population Density & 3.289 inhab $/ \mathrm{km}^{2}$ & $2.600 \mathrm{inhab} / \mathrm{km}^{2}$ & 3.902 inhab $/ \mathrm{km}^{2}$ \\
\hline Major economic activities & $\begin{array}{l}\text { Pharmacy and Health } \\
\text { Industry, Green } \\
\text { Technology, Smart } \\
\text { City Solutions, Design } \\
\text { and Creative Industry. }\end{array}$ & $\begin{array}{l}\text { Automotive Industry, } \\
\text { Chemical Industry, } \\
\text { Renewable Energies. }\end{array}$ & $\begin{array}{l}\text { Manufacturing } \\
\text { Industry, Tourism, } \\
\text { Services. }\end{array}$ \\
\hline \multicolumn{4}{|l|}{ Energy profile indicators } \\
\hline Community GHG emissions: & $\begin{array}{l}1.450 .358,00 \quad \mathrm{tCO}_{2} \\
(2016)^{*}\end{array}$ & $\begin{array}{l}9.585 .435,62 \quad \mathrm{tCO}_{2} \\
(2011)\end{array}$ & $\begin{array}{l}23.502 .100,00 \quad \mathrm{tCO}_{2} \\
(2015)^{* *}\end{array}$ \\
\hline $\begin{array}{l}\text { Annual community emissions } \\
\text { from the Transport Sector: }\end{array}$ & $\begin{array}{l}391.596,66 \quad \mathrm{tCO}_{2} \\
(2016)^{*}\end{array}$ & $\begin{array}{l}1.150 .252,27 \quad \mathrm{tCO}_{2} \\
(2011)\end{array}$ & $\begin{array}{l}16.733 .495,2 \quad \mathrm{tCO}_{2} \\
(2015)^{* * *}\end{array}$ \\
\hline $\begin{array}{l}\text { Public transportation modes } \\
\text { available: }\end{array}$ & $\begin{array}{l}\text { Trains, Bus, Metro, } \\
\text { Trams, Bike Sharing. }\end{array}$ & $\begin{array}{l}\text { Trains, Bus, Metro, } \\
\text { Trams, Bike Sharing. }\end{array}$ & $\begin{array}{l}\text { Trains, Bus, Trams, } \\
\text { Bike Sharing. }\end{array}$ \\
\hline \multicolumn{4}{|c|}{$\begin{array}{l}\text { * Data found in CDP portal (Disclosure Insight Action). }{ }^{* *} \text { Information regarding whole country } \\
\text { (Croatia). }{ }^{* * *} \text { Data related to Energy, which has included the Transportation Sector. } \\
\text { To standardize the data, the population number used is for the year of } 2015 .\end{array}$} \\
\hline
\end{tabular}

\section{Table 3. European cities' indicators used for comparison with Fortaleza}

Despite the available information about GHG emissions rate was not completely accurate and the data was collected in different years for each city, in view of the indicators, the level of GHG emissions in Fortaleza per capita is considerably bigger than in Copenhagen and Hannover. With efficient alternatives to public transportation and also reduced geographic area, Copenhagen and Hannover, face $27 \%$ and $12 \%$ of GHG emissions in the transport sector, respectively, while $61 \%$ of Fortaleza's GHG emission come from the transport sector.

Demographically, Fortaleza is bigger than the comparable European cities, however the economic aspects as tourism and industrial sector are relevant in all cities mentioned; the proximity to the coast in Zagreb is another aspect applicable to export some insights to Fortaleza. Most of European cities have well-defined weather seasons; which differently from Fortaleza, has an average temperature along the year and high humidity. 
Despite the differences, the projects analysed in the European cities take into account basic premises of sustainable development and, therefore, can be implemented in the perspective of Fortaleza. The climate alliance developed in Hannover, for example, brings a nuance of inclusion for all stakeholders in decision making that can facilitate the acceptance and engagement of those who will be most impacted by climate action.

As seen in Zagreb and Copenhagen projects, a slow change in how the city is built is imperative to change the way in which it interacts with the environment. Therefore, it is important for Fortaleza that the required improvements start to be incorporated in the rules of new constructions, starting with public buildings and extending it later throughout the city, until the entire urban network has incorporated solutions for sustainable energy and energy efficiency, as well as created more attractive spaces for active means of transport such as bicycles and pedestrians, increasingly inhibiting the use of automobiles powered by fossil fuels.

Altogether, Fortaleza has a great potential to develop alternatives and reach the targets for GHG emissions. According to the city government, in partnership with the ICLEI and other relevant institutions, the level has decreased at a rate of 49,7\% comparing 2012 with 2016, considering the Phase 1 of the LEDS's project that was implemented between 2012 and 2015 it shows a very positive outcome. In addition, this period comprised the World Cup of 2014 in Brazil, and Fortaleza was one of the host cities of the event, receiving 400,000 visitors, in that year. Compared with 2012 the GHG emissions level increased $34.3 \%[12,13,14]$.

\section{Conclusion}

Under the Urban-LEDS project, Fortaleza accepted its responsibility for its low emission development and through the GreenClimateCities (GCC) methodology to Analyze, Act and Accelerate local climate action, started to manage it. The GCC enabled the city to: mobilize key stakeholders across municipal departments; develop a greenhouse gas inventory; integrate its results with other technical studies; and ultimately embed the results into the city's political agenda for strategic sectoral action. The integrated approach adopted when making a local climate action plan and use of technical tools for evidence-based decision making is an outcome which all cities should pursue to replicate in order to establish priority actions, tailor-made approaches to tackle climate change and measurable progress indicators and metrics, as well as trigger investment from the private sector and create innovative financing models based on accurate information and forecasted results [3].

Other lessons that can be learned from Fortaleza and that can help lead to successful application of the GCC in any city are: the development of effective communication channels and the inclusion of civil society, consideration of existing agendas, policies and local issues to avoid political conflicts and establish the prioritization of the climate agenda across sectors and secretariats, proposing the finetuning or enhancement of sound practices, and creating new approaches where elements are missing.

In addition, bringing together city staff familiar with different studies from various secretariats and sectors has proven to be an advantage as it enables project decision makers to internalize technical knowledge, resulting in a quicker implementation process. Besides that, the dissemination of the GHG emissions inventory results assisted different secretariats to analyze the mitigation contribution of their 
small-scale projects, therein promoting the GCC methodology's cross-cutting approach in all sectors with the potential to mitigate GHG emissions.

Even though Fortaleza has implemented successful practices, there is always room for improvement, therefore, it should also seek connections with other cities from Brazil and internationally to learn from their experience and expertise. This paper analysed three European initiatives in three different cities that could be adapted and implemented in Fortaleza, contributing to reduce even more its GHG emissions.

The example set by Copenhagen highlights the relevance of an efficient public transport system when it comes to sustainable measures. Fortaleza must prioritize active modes of transport as well as improve the quality provided in its public transportation system in order to considerably reduce the GHG emissions related to transport, which currently represents $61 \%$ of the total emissions.

Likewise, Hannover's example brings a new perspective of cooperation between the stakeholders involved in the creation of new solutions to mitigate climate changes that should be effectively adopted when making decisions regarding this matter in Fortaleza. As well as Zagreb when it comes to its measures regarding the sustainable use of energy in the city.

Finally, it is clear that although Fortaleza is a reference when it comes to sustainable development in Brazil, its path to solving problems in relation to climate change is still being outlined. The adoption of measures that aim the promotion of active mobility, sharing transportation, incentive to reuse and recycle of materials, provision of a better urban space organization and the use of renewable energy could make the Fortaleza achieve even higher levels of sustainable standards.

\section{References}

[1] Urban LEDS 2020, Country \& City Selection Criteria, viewed 12 November 2020, <https://urbanleds.org/about-the-project/country-and-city-selection/\#1559635289646-3b061f04-45dc>.

[2] Pessoa, P.P 2014, 'Cidades sustentáveis e as fronteiras de risco e respeito ao sistema socioambiental de Fortaleza, CE' Master's Thesis, Universidade de Brasília, viewed 12 November 2020, < https://core.ac.uk/download/pdf/33549131.pdf>.

[3] ICLEI Case Studies 2016, Integrating greenhouse gas inventories as a decision making tool for informed action, viewed $15 \quad$ November 2020, < http://old.iclei.org/fileadmin/PUBLICATIONS/Case_Studies/ICLEI_cs_192_Fortaleza_UrbanLED S.pdf>.

[4] IUC International Urban Cooperation 2017, Planejamento Urbano de Baixo Carbono Caso: Fortaleza/CE, viewed 14 November 2020, < http://iuc-la.eu/wpcontent/uploads/2020/03/POR_Fortaleza_CE_-

Pol\%C3\%ADtica_de_Desenvolvimento_Urbano_de_Baixo_Carbono.pdf>.

[5] Silva, E.M, Pereira, C, Uriona, M.M, Vaz, C. \& Luna, T., 2018, 'Buscando a mobilidade sustentável: impacto do projeto VAMO de carros elétricos compartilhados por cenários simulados', paper presented to XXXVIII Encontro Nacional de Engenharia de Produção, 16-19 October, viewed 14 
https://www.researchgate.net/publication/335681888_BUSCANDO_A_MOBILIDADE_SUSTENT AVEL_IMPACTO_DO_PROJETO_VAMO_DE_CARROS_ELETRICOS_COMPARTILHADOS_POR_CENAR IOS_SIMULADOS>.

[6] UN-HABITAT 2019, 'Urban LEDS II Newsletter \#2, viewed 17 November 2020, < https://unhabitat.org/urban-leds-ii-newsletter-2>.

[7] OECD 2009, 'Territorial reviews: Copenhagen,Denmark', preliminary draft, viewed 15 November 2020, <https://www.oecd.org/gov/oecdterritorialreviewscopenhagendenmark.htm>.

[8] ICLEI Case Stories 2015, 'The Nørrebrogade Project: revitalizing a major road corridor for enhanced public transport and urban life', viewed 12 November 2020, <https://urbanleds.org/wpcontent/uploads/2019/resources/case_studies/UrbanLEDS_case_story_Copenhagen_2015_Web .pdf.>.

[9] Yanrong, K., Lei, Z., Cai, C., Yuming, G., Hao, L., Ying, C., \& Xiaxia, J., 2014, 'Comparative study of smart cities in Europe and China 2014' Springer, https://doi.org/10.1007/978-3-662-46867-8

[10] Intelligent Energy Europe 2014. 'Zagreb - Energy Efficient city (ZAGEE)', viewed 28 December 2020, <https://ec.europa.eu/energy/intelligent/projects/en/projects/zagee>.

[11] City of Hannover 2010. 'Stadtwerke Hannover Ag. Climate Alliance Hannover 2020.: a strong alliance for climate protection', viewed 01 December 2020, < https://www.readkong.com/page/for-climate-protection-hannover-de-4841915>.

[12] Alves, G, Marinho, M. M. 0, 2015, 'Inventários Urbanos de Emissões de Gases de Efeito Estufa no Brasil: Uma Análise Preliminar' paper presented to Encontro Internacional sobre Gestão Empresarial e Meio Ambiente - ENGEMA, viewed 10 November 2020, <http://engemausp.submissao.com.br/17/anais/arquivos/307.pdf>.

[13] Fortaleza 2014, 'Inventário de Emissões de GEE do Município de Fortaleza', viewed 13 December $2020,<$ http://www.fortaleza.ce.gov.br/sites/default/files/inventario_da_emissao_dos_gases_do_ efeito_estufa.pdf $>$.

[14] Fortaleza 2016, 'Inventário de Emissões de GEE do Município de Fortaleza', viewed 13 December 2020, <https://urbanismoemeioambiente.fortaleza.ce.gov.br/images/urbanismo-e-meioambiente/forclima/22-03-

2019_3_inventario_de_emissoes_de_gases_do_efeito_estufa_de_fortaleza_ano_base_2016.pdf >. 